\title{
A MODEL FOR ENGAGING STUDENTS, COMMUNITIES AND COLLEGES THROUGH THE INTEGRATION OF SERVICE-LEARNING PROJECTS INTO INFORMATION SYSTEMS COURSES
}

\author{
Paul J. Kovacs, Robert Morris University, kovacs@rmu.edu \\ Gayle Jesse, Thiel College, giesse@thiel.edu \\ Lisa Kovalchick, California University of Pennsylvania, kovalchick@calu.edu
}

\begin{abstract}
As educators we often consider the following question. How do I engage students in my classroom? Engaging students in the classroom is frequently difficult to accomplish in a technology driven society where educators compete for a student's attention with texting, Facebook and Twitter. The purpose of this paper is to present a solution to educators that will assist them in engaging students in the classroom. This paper discusses several service-learning projects and compares the advantages and disadvantages of completing a simulated project versus a service-learning project in a senior-level Web portfolio course. A project based model is used for teaching this course and is discussed in detail, educators are encouraged to use this project based model as a guide in leading students through a successful service-learning project. This paper concludes with the idea that service-learning projects engage all parties involved and should be considered when designing the pedagogy for a Web portfolio course. This study, together with many others referenced in this paper, finds that service-learning projects provide a framework for engaging students in the classroom.
\end{abstract}

Keywords: Service-learning, Web design course model, Project Based Learning, Teaching Web Development Course

\section{INTRODUCTION}

One major goal of most educators should be to have student engagement in the classroom. What does being engaged in the classroom mean? Linda Deneen [2], EDUCAUSE columnist, found that George Kuh's definition illustrates this complexity of student engagement. George Kuh's definition: The engagement premise is straightforward and easily understood: the more students study a subject, the more they know about it, and the more students practice and get feedback from faculty and staff members on their writing and collaborative problem solving, the deeper they come to understand what they are learning and the more adept they become at managing complexity, tolerating ambiguity and working with people from different backgrounds or with different views [9]. The authors agree with Kuh but would also like to add that we have found, in our classrooms, engaged students are students who are involved. In order to have involved students, the students must be immersed in the topic and absorbing the course material. How do educators engage students in the classroom? Engaging the student in the classroom is the most difficult task of an educator given the way today's society operates. Society as we know it has changed dramatically in the past 15-20 years due to the Internet and computerized technologies and it has changed the way we live. Therefore, educators have had to change the way they teach students in order to be able to compete for the engagement of students in the classroom due to smart phones, the iPad and social networking sites to name just a few. The authors of this paper feel strongly that integrating "service-learning" projects into the curriculum is an effective way to engage students. This paper discusses service-learning projects (SLPs) and the facts gathered by the authors on the successful completion of SLPs.

\section{SERVICE LEARNING PROJECTS (SLPs)}

\section{What are SLPs?}

Service-Learning Projects or SLPs are defined by the Corporation for National and Community Service (CNCS) as follows: Service-learning is a teaching and learning strategy that integrates meaningful community service with 


\section{Issues in Information Systems}

Volume 13, Issue 1, pp. 310-320, 2012

instruction and reflection to enrich the learning experience, teach civic responsibility and strengthen communities [20].

\section{Why are SLPs important?}

The CNCS states that: Service-learning is a structured learning experience that combines community service with preparation and reflection [20]. The keywords here to educators are structured, prepared and reflection. This paper presents a model for completing SLPs that are structured, determines if students are prepared for their career and allows for reflection on project completion. Service-learning projects are becoming a phenomenon and national movements are taking place in schools to incorporate active and collaborative learning activities into curriculum. Why are SLPs a phenomenon? CNCS declares that service-learning provides college and university students with a "community context" to their education, allowing them to connect their academic coursework to their roles as citizens [20]. Therefore, could SLPs be the answer for educators being able to engage or involve students in the classroom?

\section{SUPPORTING RESEARCH FOR SERVICE LEARNING PROJECTS}

Connors [1] research in service-learning informs educators that SLPs have gained recognition as an effective curricular strategy. Research states that SLPs prepare students for their roles as professionals and citizens, change the way faculty teach, change the way higher education programs relate to their communities, enable community organizations and community members to play significant roles in how students are educated and enhance community capacity; further supporting evidence of this research follows.

\section{Students}

Seifer [21] and Furco [6] indicate that service-learning is a form of experiential learning, which makes SLPs transformational. SLPs depart from traditional models of learning; especially in the area of reflection and more specifically SLPs can have a more collaborative grounding on how the information systems course goals and objectives will be defined as well as how the information systems course curriculum will be structured. Kolb [8] created a model that describes the key stages that students will cycle through in their educational processes which proves the pedagogical effectiveness of SLPs:

1. concrete experiences;

2. reflective observation;

3. abstract conceptualization;

4. active experimentation.

Additional research $[13,15,18]$ indicate the following further benefits from the perspective of the students.

- strength of interdisciplinary teamwork

- social awareness and social justice

- articulation of their own professional role

- problem-solving skills

- priority setting

- understanding of cultural and rural perspectives

- more socialized into the profession

- gain personal insight into moral sensitivity

- connect theory and practice

- develop critical thinking

\section{Faculty}

As current faculty members that have experience in conducting many successful SLPs, the authors agree with other service-learning researchers that SLPs provide faculty with the following benefits: increase community 


\section{Issues in Information Systems \\ Volume 13, Issue 1, pp. 310-320, 2012}

understanding among faculty and bring new directions and confidence to the teaching and scholarly pursuits of the faculty involved. Research conducted by Seifer [21] and Furco [6] from a service-learning Curriculum Development Manual revealed the following benefits to faculty towards course objectives when completing SLPs:

- $\quad$ students learn by doing because learning by doing is at the center of discovery;

- students learn by completing ongoing critical reflection on what is being experienced for effective learning;

- students are engaged in the course because they have the opportunity to help to direct and shape the learning experiences within the SLP;

- students are learning new knowledge along with concepts and skills which then are linked in meaningful ways to the learner's personal experiences.

With all the advantages of completing SLPs, there are several disadvantages to be noted. Faculty productivity may be impacted and faculty may experience the following increases to their workload:

- increased time commitment - answering student questions and communication with the community organizations;

- increased work - management of the service-learning project means making sure the project is completing the course objectives, as well as, fulfilling regular campus/faculty commitments and possibly maintaining an ongoing relationship and commitment to the various projects;

- increased enthusiasm commitment - SLPs become a personal commitment and enthusiasm towards the projects must remain high to have success in adding this learning to the pedagogy of a course and success in working with the community.

Other disadvantages or limitations of SLPs include: confinement to the semester schedule/academic year, proper placement of the project in the student's curriculum (careful planning overcomes this issue; the authors use this as senior-level course) and community partners need to be aware of university policies regarding procedures [16]. The authors of this paper have created a contract for both the learning institution to sign and the community partner which clarifies the role of the involved parties.

\section{Academic Institutions}

SLPs are a vehicle for moving academic institutions towards increased engagement within the community and ultimately change the way higher education programs relate to their communities. Furthermore, academic institutions that encourage faculty members to conduct SLPs possess the ability to develop and strengthen their community and are viewed by the community as resources. A thorough analysis of research in the area of "Service Learning in Writing Courses" [11, 13, 15, 18] establishes the following additional benefits from the perspective of the academic institution.

- providing a visible link with the community;

- formation of collaborative relationships;

- faculty and student involvement in local and state issues;

- increased preparation of graduates;

- enhanced appeal to potential financial donors and volunteers of the institution.

Seifer and Connors [20] found from evaluations that in order for higher educational institutions to build institutional capacity around service-learning, they need to clearly define their mission and goals, generate multi-level support, invest in faculty development, nurture long-term community partnerships and integrate service-learning into the administrative structures and policies of the institution as well as the broader curriculum. Additionally, Kuh [9], states that institutions that "live" or meet their mission are the schools that are impressive in fostering student engagement. Service-learning projects immensely express the way an institution can "live" their mission. 


\section{Issues in Information Systems}

Volume 13, Issue 1, pp. 310-320, 2012

\section{Community}

Community organizations that participate in SLPs contribute to economic, operational and social benefits of the projects. The authors found that since SLPs involve the student and community, students are liking to be engaged in the community; an affect that is real and creates lasting social change. The following research was also gathered by a number of authors $[11,13,15,18]$; "Service Learning in Writing Courses" showed the following benefits from the perspective of the community.

- $\quad$ short- and long-term solutions to problems;

- access to campus resources;

- opportunities to contribute to the educational preparation of students.

The authors agree with Seifer and Connors [20] that academic institutions often enter into a SLP intending to "fix" and to "help" the community organization; however, sometimes this mindset is not the best approach. Community organizations need to establish their own vision for the future and the strategies for getting there. If this does not happen, most university actions are not likely to affect real and lasting change. A better approach is to help the community organization "develop" versus "fix", so the community organization and can build upon the university developments.

\section{SLPS VERSUS SIMULATED COURSE PROJECTS}

After analyzing the advantages and disadvantages of SLPs, the authors of this paper created two tables displaying the advantages and disadvantages of SLPs versus simulated projects based on the completion of many SLPs and simulated course projects.

Table 1. SLPs

\begin{tabular}{|c|c|}
\hline \multicolumn{2}{|c|}{ SLPs } \\
\hline Advantages & Disadvantages \\
\hline $\begin{array}{l}\text { - Working with an actual end-user } \\
\text { Improves: } \\
\circ \quad \text { interviewing } \\
\circ \quad \text { problem solving } \\
\circ \quad \text { conflict resolution } \\
\circ \quad \text { oral and written communication skills } \\
\text { - Projects have "real" meaning, not } \\
\text { artificially invented } \\
\text { - Promotes industry/university relationships } \\
\text { - Potential employee source }\end{array}$ & $\begin{array}{ll}\text { - } & \text { Time consuming } \\
\text { - } & \text { Risk taking in a non-controlled } \\
\text { environment } \\
\text { - } \quad \text { Possible conflict with user } \\
\text { - Incomplete project can be a major issue } \\
\text { - } \quad \text { Group conflicts }\end{array}$ \\
\hline
\end{tabular}

Table 2. Simulated Course Projects

\begin{tabular}{|ll|l|}
\hline \multicolumn{2}{|c|}{ Simulated Projects } \\
\hline \multicolumn{1}{|c|}{ Advantages } & \multicolumn{1}{c|}{ Disadvantages } \\
\hline $\begin{array}{l}\text { Working with a knowledgeable end-user } \\
\text { (instructor) }\end{array}$ & $\bullet$ & $\begin{array}{l}\text { Marginal decision making and problem } \\
\text { solving experiences }\end{array}$ \\
- $\begin{array}{l}\text { Limited community involvement } \\
\text { Perceived "equity" among project groups }\end{array}$ & - $\begin{array}{l}\text { Insignificant risk taking practice } \\
\text { - Incks external resources and contacts }\end{array}$ \\
& - $\begin{array}{l}\text { Perception that end-user (instructor) has all } \\
\text { of the answers }\end{array}$ \\
\hline
\end{tabular}




\section{Issues in Information Systems}

Volume 13, Issue 1, pp. 310-320, 2012

\section{COURSE ORGANIZATION AND EXAMPLES}

Beginning an SLP can be a challenge. Rodgers [19] suggests that by completing the following three steps, implementation of this new pedagogy will be a success. The first step is to find a good match between academia and the community organization. The second step requires a formation of a strong relationship between the two. The third step involves making sure the role of expectation has been clarified.

A senior-level Web portfolio course at one author's institution made use of SLPs; the participating community organizations were The Literacy Council and Holy Trinity Lutheran Church. The purpose of both projects was to re-design their "entire" current Web sites. The Literacy Council initiated the contact with the authors College in regards to redevelopment of their Web site. However, the faculty member initiated contact with Holy Trinity to redesign their site. The SLPs were completed by two students for the Literacy Council and three students completed the Holy Trinity site. The address of the completed site for the Literacy Council is http://www.the-literacycouncil.org/. Holy Trinity chose not use the re-designed site, the current site can be found at http://www.holytrinitygreenville.org/. Figure 1 displays a screen shot of the home page of the re-designed Holy Trinity site, at the completion of the SLP.

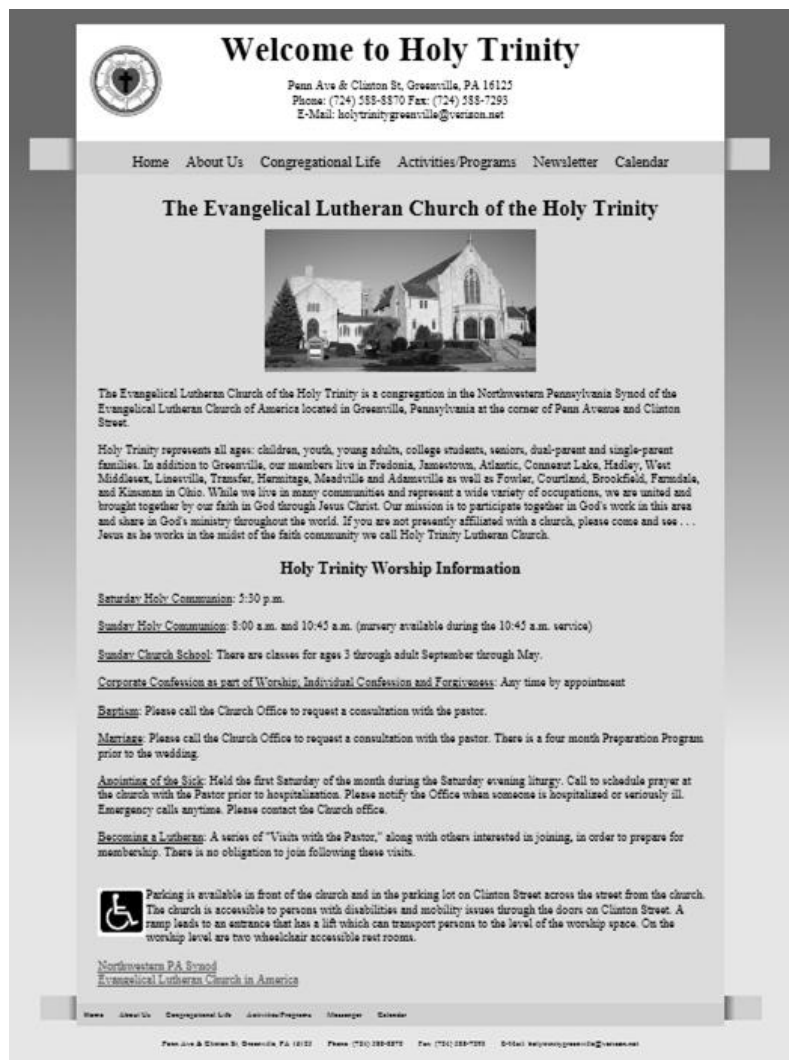

Figure 1. Holy Trinity re-designed Web site

An advanced Web site design and e-commerce course at another author's university involved two additional SLPs, which included the development of interactive data-base driven Web sites. One SLP consisted of a career posting site for a local entrepreneur that allowed companies and candidates to post their new job opportunities and profiles, respectively. The other SLP involved the design of a local auto parts store Web site, in which users could search for and order parts. Each project had no more than six components and involved a group of seven students. The career 


\section{Issues in Information Systems}

Volume 13, Issue 1, pp. 310-320, 2012

posting site was live for approximately 3 years. The auto parts application never went live; however, it was completed.

A final example involved a two-semester, senior-level capstone course at another author's university. The first semester of the course focuses on the systems analysis component of the project, while the second semester is used for implementation of the project. A group of five students worked together to create an asset tracking system utilizing a database management system with a Web-based front end for data entry and user interaction. This system was developed for a local non-profit organization with sixty offices in two counties near the university. The system is capable of tracking and monitoring equipment and includes an automated request and approval process for relocation, updating and maintenance of assets. This project was completed and is currently in use at the non-profit organization.

In addition to Rodgers [19], the authors suggest using the project-based model they created to assist in the implementation of SLPs into information systems course pedagogy. The project based model in Figure 2 illustrates the course steps, followed by a brief discussion of specific issues regarding each step.

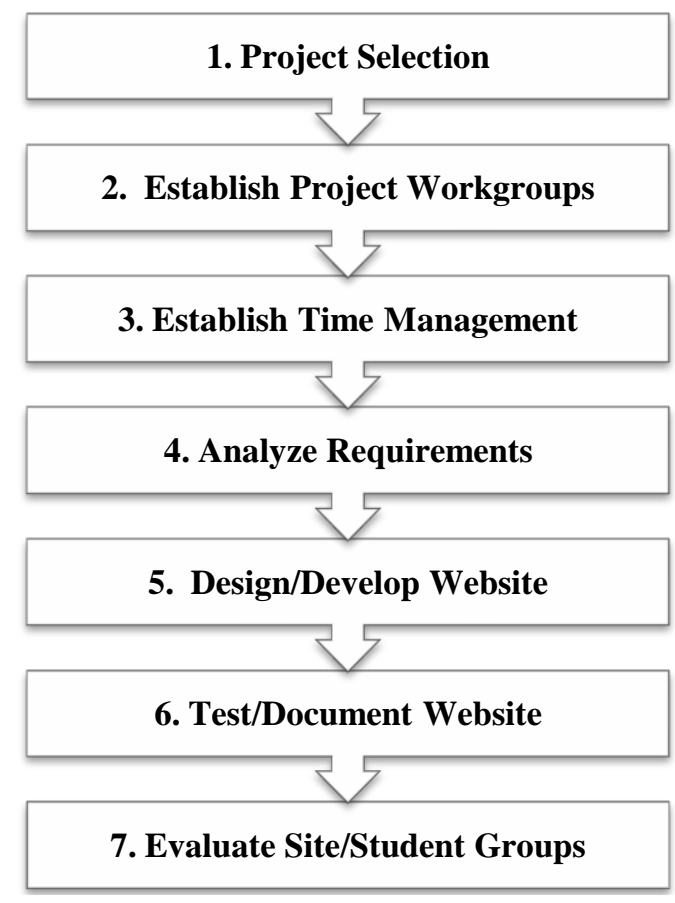

Figure 2. Project Based Model

\section{Project Selection}

The advantages and disadvantages of simulated projects and SLPs were previously discussed in this paper. Understanding the advantages and disadvantages of each project type will aid in determining which project best suits the needs of the instructor and the students. The selection of an appropriate project is extremely important.

In a simulated project, the instructor creates a scenario and acts as the user. A simulated project allows for a great deal of control over the system requirements. However, the main pitfall to avoid is the selection of a project whose subject material is beyond the scope and interest of the students. Subject matter that is of interest to all students and that can be readily compartmentalized will permit a focus on the objectives that are most important for the class. 


\section{Issues in Information Systems \\ Volume 13, Issue 1, pp. 310-320, 2012}

Uncompleted simulated projects only result in lowering the grade of individuals within the group or the group as a whole.

In a SLP, a client, such as the instructor, the student, the college/university, a community organization or a business can initiate a "real-world" project and then the students work with the client in order to complete the project. Since the SLP solves a "real-world" problem and is likely to be implemented at the client's place of business, students often become very interested in the project and put extra effort into the completion of the project. Conversely, because the requirements come from an actual end-user with a "real-world" project, particular attention must be given to scope creep and time management issues because the students have only a semester to complete the project. It is extremely important to note that another group, the instructor or another student must finish uncompleted realworld projects. Creating a contract between the involved parties can create a safe guard from this happening.

\section{Establish Project Workgroups}

The construction of a Web site is accomplished as a group as part of a Web development team. According to Mohler [14] the team roles can include technical designer, media designer, information design specialist, Internet specialist and technical manager. Shelly, Cashman, \& Rosenblatt [22] list six diverse roles as writer/editor, multimedia developer, artist/graphic designer, Web page designer, Web programmer and Webmaster. Stein [23] lists four diverse roles as Web Administrator, Web author, Web Script developer and Webmaster. In the development of larger, database-driven Web site projects, the authors have used additional roles, such as database designer and project manager.

To assist the instructor in establishing workgroups a student self-assessment can be administrated as well as an assessment of student knowledge in the area of Web design concepts. This can determine the experience each student has on a number of important criteria. Group size is determined by the class size and the number of project components of the Web site. Having too few students in a group can place too high of a workload on each student, while having too many students in a group can result in some group members completing little to no work on the project. Experience suggests that no more than eight students per workgroup is an ideal number.

\section{Establish Time Management}

The instructor and each project team must decide on time management issues. There are two ways to approach this: (1) by requiring that a specific component of the project be completed by a specific date in the semester or (2) by having the students manage their own time with a final due date. The first approach gives the instructor control and the second approach gives the students the responsibility for completion of the project. The authors' experience suggests that the first approach works best.

\section{Analyze Requirements}

Following the formation of workgroups and the establishment of time management constraints, each project team conducts a needs assessment. This needs assessment closely follows the analysis step in the traditional systems development life cycle (SDLC) [7, 22, 24]. Data is collected from the end-user pertaining to the scope of the project, which includes the purpose and target customers, as well as, the Web server needs in relation to expected site traffic and traffic growth and graphics.

\section{Design/Develop Website}

Once each group has gathered and analyzed content and the instructor approves that content, the process of designing and developing the Web site can begin. This step follows the systems design step in the traditional SDLC and the instructor role is that of a project leader. How the design and development is accomplished is up to each group. For example, since each site will need to have a home page, often all group members will be responsible for its development. For content pages, graphics and database design, members of each group may want to work individually or collaborate with another group member. One author's experience suggests that the instructor choose a student in the group to be the project manager to avoid miss communication while another author allows the students to choose a project manager for their team. The project manager gains experience in management by answering questions, making final decisions and delegating tasks. 


\section{Issues in Information Systems \\ Volume 13, Issue 1, pp. 310-320, 2012}

This development normally takes take place in the schools' computer lab or on a student's personal computer. However, some development may take place at the client's place of business, depending on Web server and hosting requirements. Each group is required to meet with the instructor every week and provide the progress completed.

\section{Test/Document Website}

A deadline should be set for the completion of the project approximately two weeks before the end of the semester. At this time, all groups will meet with their clients to present their Web sites. Each organization will provide the group with changes and the groups will have approximately two weeks to make the changes and conduct final testing of the Web site.

\section{Evaluate Site/Student Groups}

The completed project, the contribution of individuals to each group and the student's knowledge on Web site design is the basis for grading of the course. The authors have found the following breakdown to be the most practical.

Student knowledge of Web design: During the review of Web design concepts, the traditional textbook/lecture approach is used and the students complete a number of assignments/exercises/quizzes. These activities comprise a 10 percent of the final grade.

Individual contributions to the group: Each student's individual contribution to the group is the basis for another 20 percent of the final grade. Rather than the instructor making this determination solely through his/her observation, individual group members will evaluate each other as per an anonymous evaluation sheet constructed by the instructor.

Completed Project: The completed project accounts for the largest percentage of the final grade, 50 percent. The project grade is divided into several components. The deliverables the instructor has collected during the weekly meeting comprises one component, while another component is the degree of completion of the project, based upon the overall requirements.

Reflections: The authors agree with Kolb [8] that SLPs should contain a reflection portion to the course. Reflections are worth 20 percent of the final grade. A second Kolb [8] model suggests that when one learns from experience, one goes through a three-step cycle: (1) start with a concrete experience, (2) consider reflective observations and (3) process information through abstraction and conceptualization. The authors have two suggestions for following through with Kolb's model and focusing the students when writing reflections: (1) have the students answer the following questions. Why? What? So, what? Now what? [20]; and (2) using "critical incidents", which require more discipline and critical thinking; a tool that can be used more realistically in the student's career.

\section{COURSE ASSESSMENT}

\section{Teaching and Learning Environment}

To create an engaged and effective teaching and learning environment, Seifer and Connors [20], provide the following key definitions.

- Educational Outcomes: Educational outcomes provide evidence showing the degree to which program purposes and objectives are or are not being attained, including achievement of appropriate skills and competencies by students.

- Learning Objectives: The learning objectives describe the outcome competencies learners should acquire or achieve as a result of the course or curriculum. They also help provide a "road map" for planning course instruction, and define the standards or criteria by which successful learning will be measured. 


\section{Issues in Information Systems \\ Volume 13, Issue 1, pp. 310-320, 2012}

- Competencies: Competencies are the set of knowledge, skills and behaviors that are necessary for effective practice in a particular field or profession.

Figure 3 is a model that can serve as an aid for an instructor when designing a course. This model will ensure that the instructor is meeting both the institutional standards and accrediting body standards.

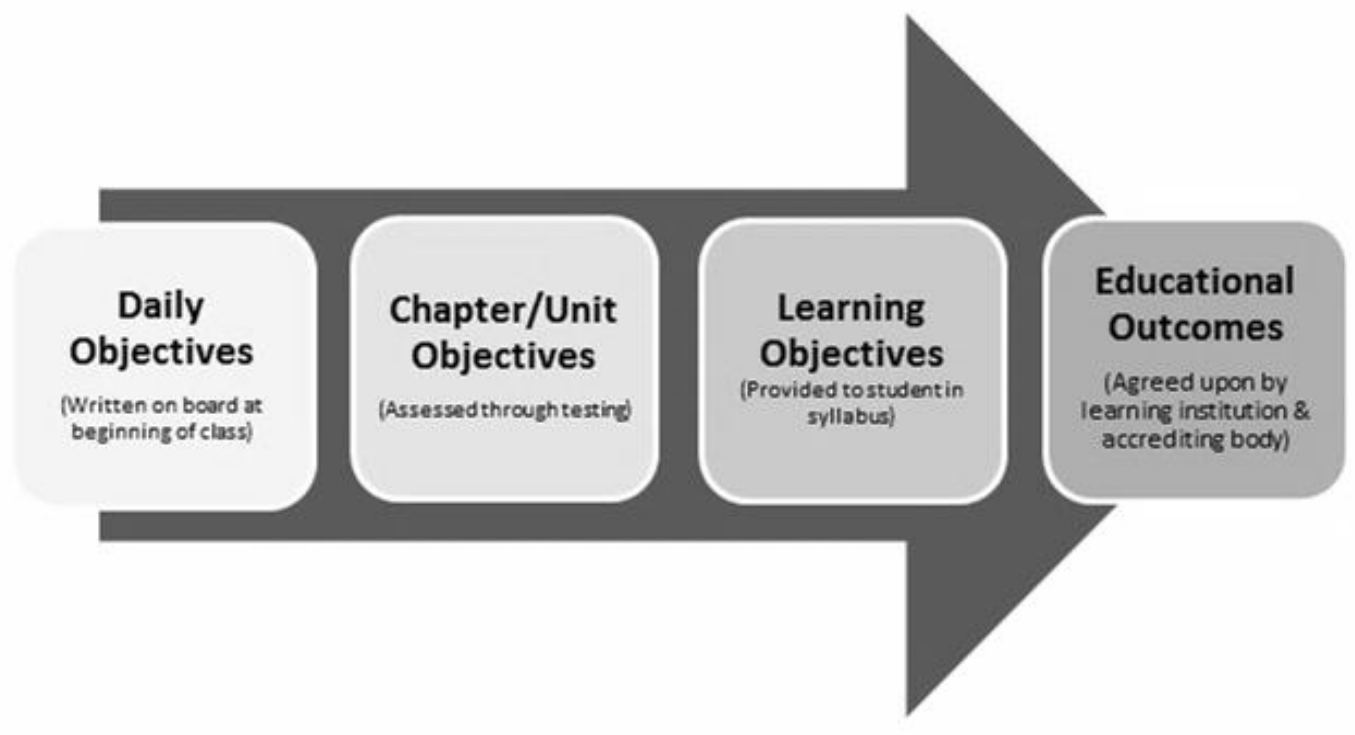

Figure 3. Assessment Model for Course Design

To aid in the creation of learning objectives, the findings of many of the researchers referenced in this paper show that some the student learning outcomes include personal development, interpersonal development and academic learning. Preiser-Houy et al. [17] stated the following:

1. personal development outcome is comprised of self-knowledge and personal efficacy;

2. interpersonal development outcome consists of communication, collaboration and leadership skills; and

3. student academic learning encompasses domain specific and general knowledge and skills.

\section{CONCLUSION}

Why do university educators want to engage students? Through our own observations, as long-time educators in information systems, the authors feel that engaging students with the institution attracts students, ties them to us, makes them part of our community and motivates them to succeed in their academic careers. As faculty members, we know student retention is a high priority among academic institution administrations and SLPs are a method for engaging and entangling students in our institutions in multiple and positive ways that helps them to remain with us, learn more effectively, enjoy their student experience and prepare for life outside higher education [2]. SLPs are more engaging for students versus a traditional course because SLPs create a "vested interest" toward their successful completion. Additionally, integrating SLPs into the higher education curriculum engages students in the classroom, which in return enhances student learning. To prove the main idea of this paper: SLPs make students feel more engaged in the classroom, one author interviewed, via e-mail, several students who completed SLPs and obtained three supporting student responses. In the e-mail interview, the author provided the following definition of engage: to occupy the attention of or efforts of, and the following interview question was asked: Did you feel engaged in class because the service-learning project was a live or "real world" project? Yes or No, Why? Several responses from students are as follows: 


\section{Issues in Information Systems \\ Volume 13, Issue 1, pp. 310-320, 2012}

Response \#1 - "The service-learning project did make me feel engaged in class because it allowed me to interact with my peers as if they were colleagues. This was a good experience to better prepare me for postgraduation employment. The SLP also allowed me to take the classwork that I had learned over the previous 4 years and apply it to a Web site that would be used in the future and viewed by a target audience." This particular student had only completed one SLP, graduated last year and is currently working in a Web maintenance position.

Response \#2 - "When working on the project Web site, I did feel more engaged in class. Knowing that this was my final project was definitely a strong motivator to make sure it was complete and at its best quality. I think that it was a great experience because we were able to combine all that we had learned so far within our courses and we were also able to interact with an actual client and all of the interactions that this entailed." Presently, this student is senior and already has a Web programming job lined up after graduation.

Response \#3 - "I feel like the project of completing the SLP Web site made me feel more engaging in class because I felt like wanted to do a good job on it. I had in the back of my mind that the public would be able to see my final project. The service project was a helpful tool in getting to know more about things outside of class, it made me want to learn more about things Web site development that I did know before. It was also engaging and kept my attention when I needed to complete task, I felt like I wanted to work on the service project more than a regular project. Overall the service project was a good learning experience." Currently, this student is a junior and will be completing another SLP before graduation.

Finally, SLPs and/or project-based learning, unlike the traditional textbook/lecture approach, motivate the students to do additional work, illustrate to the students the value of the educational outcomes covered and most importantly, provide practical experiences that enrich the student's academic experiences. Through our own observation and reflection, the authors felt, each project was successful because of the collaborative efforts and engagement on all sides of the relationships. The addition of SLPs into information systems course pedagogy is a large project; therefore, consider these final thoughts: early planning is required for the completion of the SLP due to semester time constraints, SLPs are time consuming and require ongoing communications and budgeting time is important during and at the end of the semester for students to fully reflect and present on the learning involved in the SLP. SLPs implemented into the curriculum are time consuming but have a value in the development of critical thinking and performance of skills for students due to the student being engaged in the classroom. They also provide realworld experience that students can include on their resumes, enhancing the students' employment outlook.

\section{REFERENCES}

1. Connors, K., Kirk H., \& Seifer, S.D. (2000). "Improving the preparation of nursing professionals through community-campus partnerships", In Gott, M. (Ed), Nursing Practice, Policy and Change, Radcliffe Medical Press.

2. Deneen, L. “What Is Student Engagement, Anyway?” EDUCAUSE Quarterly, vol 33, no. 1 (2010). Retrieved April 15, 2012, from http://www.educause.edu/EDUCAUSE+Quarterly/EDUCAUSEQuarterlyMagazineVolum/WhatemIsemStudent EngagementAny/199393.

3. Engage - Dictionary.com. (n.d.). Dictionary.com. Retrieved April 15, 2012, from dictionary.reference.com/browse/engage

4. Engagement : Oxford English Dictionary. (n.d.). Engagement : Oxford English Dictionary. Retrieved April 15, 2012, from http://oed.com

5. Eyler, J., \& Giles, D. (1999). Where's the learning in service-learning? San Francisco, CA: Jossey-Bass.

6. Furco, A. (1996). "Service-learning: a balanced approach to experiential education" In B. Taylor (Ed.), Expanding Boundaries: Serving and Learning. Washington, DC: Corporation for National Service.

7. Kendall, K., \& Kendall, J. (2003). Systems analysis and design Sixth Edition. Upper Saddle River, NJ: Pearson Prentice Hall.

8. Kolb D. A. (1984). Experiential learning: experience as the source of learning and development. Englewood Cliffs, NJ: Prentice-Hall. 


\section{Issues in Information Systems}

Volume 13, Issue 1, pp. 310-320, 2012

9. Kuh, G. D. (2005). Student success in college: creating conditions that matter. San Francisco, CA: Jossey-Bass.

10. Kuh, G. D. (2009). The national survey of student engagement: conceptual and empirical foundations, New Directions for Institutional Research, 141, 5-20.

11. Mareck, D. G., Uden, D. L., Larson, T. A., Shephard, M. F., \& Reinert, R. J. (2004). Rural interprofessional service learning: the Minnesota experience. Academic Medicine, 79(7), 672-676.

12. Joseph, M., Stone, G., Grantham, K., Harmancioglu, N., \& Ibrahim, E. (2007). An exploratory study on the value of service learning projects and their impact on community service involvement and critical thinking. Quality Assurance in Education: An International Perspective, 15(3), 318-333. Retrieved from EBSCOhost.

13. Mayne, L., \& Glascoff, M. (2002). Service-learning: preparing a healthcare workforce for the next century. Nurse Educator, 27(4), 191-194.

14. Mohler, J. (1997). How to become a webmaster in 14 days. Indianapolis, IN: Sams.net.

15. Mueller, C., \& Billings, D. (2009). Service-learning: developing values and social responsibilities. In D. M. Billings \& J. A. Halstead (Eds.), Teaching in nursing: A guide for faculty $\left(3^{\text {rd }}\right.$ ed.). St. Louis, MO: Elsevier Saunders.

16. Peterson, B., Yockey, J., Larsen, P., Twidwell, D., \& Jorgensen, K. (2006). Service-learning projects: meeting community needs. Home Health Care Management \& Practice, 18(4), 315-322.

17. Preiser-Houy, L., \& Navarrete, C. (2006). Exploring the learning in service-learning: a case of a communitybased research project in web-based systems development. Journal of Information Systems Education, 17(3), 273-284.

18. Redman, R. W., \& Clark, L. (2002). Service-learning as a model for integrating social justice in the nursing curriculum. Journal of Nursing Education, 41(10), 446-449.

19. Rodgers, M. W. (2001). Service-learning: resource allocation. Nurse Educator, 26(5), 244-247.

20. Seifer S. D., \& Connors K. (2007). Community campus partnerships for health. faculty toolkit for servicelearning in higher education. Scotts Valley, CA: National Service-Learning Clearinghouse.

21. Seifer, S. D. (1998). Service-Learning: community-campus partnerships for health professions education. Academic Medicine, 73(3), 273-277.

22. Shelly, G., Cashman, T., \& Rosenblatt, H. (2003). Systems analysis and design Fifth Edition. Cambridge, MA: Course Technology.

23. Stein, L. (1997) How to set up and maintain a web site. Reading, MA: Addison Wesley University Press.

24. Whitten, J., Bentley, L., \& Dittman, K. (2004). Systems analysis and design methods Sixth Edition. New York, NY: McGraw Hill/Irwin. 